Article

\title{
Effects of the Amino Acid Constituents of Microcystin Variants on Cytotoxicity to Primary Cultured Rat Hepatocytes
}

Kumiko Shimizu ${ }^{1, *}$, Tomoharu Sano ${ }^{2}$, Reiji Kubota ${ }^{1}$, Norihiro Kobayashi ${ }^{1}$, Maiko Tahara ${ }^{1}$, Tomoko Obama ${ }^{1}$, Naoki Sugimoto ${ }^{3}$, Tetsuji Nishimura ${ }^{4}$ and Yoshiaki Ikarashi ${ }^{1}$

1 Division of Environmental Chemistry, National Institute of Health Sciences, 1-18-1 Kamiyoga, Setagaya-ku, Tokyo 158-8501, Japan; E-Mails: reijik@nihs.go.jp (R.K.); norihiro.kobayashi@nihs.go.jp (N.K.); tahara@nihs.go.jp (M.T.); obama@nihs.go.jp (T.O.); ikarashi@nihs.go.jp (Y.I.)

2 Center for Environmental Measurement and Analysis, National Institute for Environmental Studies, 16-2 Onogawa, Tsukuba-shi, Ibaraki 305-8506, Japan; E-Mail: sanotomo@nies.go.jp

3 Division of Food Additives, National Institute of Health Sciences, 1-18-1 Kamiyoga, Setagaya-ku, Tokyo 158-8501, Japan; E-Mail: nsugimot@nihs.go.jp

4 Faculty of Pharmaceutical Sciences, Teikyo Heisei University, Nakano 4-21-2, Nakano-ku, Tokyo 164-8530, Japan; E-Mail: t.nishimura@thu.ac.jp

* Author to whom correspondence should be addressed; E-Mail: kshimizu@nihs.go.jp; Tel.: +81-3-3700-9304; Fax: +81-3-3700-9304.

Received: 13 November 2013; in revised form: 13 December 2013 / Accepted: 24 December 2013 / Published: 30 December 2013

\begin{abstract}
Microcystins, which are cyclic heptapeptides produced by some cyanobacterial species from algal blooms, strongly inhibit serine/threonine protein phosphatase and are known as hepatotoxins. Microcystins have many structural variations, yet insufficient information is available on the differences in the cytotoxic potentials among the structural variants. In this study, the cytotoxicities of 16 microcystin variants at concentrations of $0.03-10 \mu \mathrm{g} / \mathrm{mL}$ to primary cultured rat hepatocytes were determined by measuring cellular ATP content, and subsequently determined by their $50 \%$ inhibitory concentration $\left(\mathrm{IC}_{50}\right)$. Differences in the amino acid constituents were associated with differences in cytotoxic potential. [D-Asp $\left.{ }^{3}, Z-\mathrm{Dhb}^{7}\right]$ microcystin-LR exhibited the strongest cytotoxicity at $\mathrm{IC}_{50}$ of $0.053 \mu \mathrm{g} / \mathrm{mL}$ among the microcystin variants tested. Furthermore, [D-Asp ${ }^{3}, Z$-Dhb ${ }^{7}$ ] microcystin-HtyR was also highly cytotoxic. These results suggest that both D-Asp and $Z$-Dhb residues are important in determining the cytotoxic potential of microcystin variants.
\end{abstract}


Keywords: microcystin; variants; cytotoxicity; primary cultured rat hepatocytes; environmental water

\section{Introduction}

Algal blooms consist of the overgrowth of cyanobacteria in nutrient-rich standing water. When the occurring species produces toxins, these water blooms are hazardous to wildlife, livestock, humans and environmental water systems. Some cyanobacteria species, such as Microcystis, produce microcystins (MCs), which are potent hepatotoxins [1-4]. Moreover, because global warming causes an increase in the occurrence of blooms, there are concerns that MC variants may result in enhanced health hazards for people in countries under the subtropic and temperate region $[5,6]$.

MCs are macrocyclic heptapeptides with the principal amino acids sequence, cyclo-(D-Ala ${ }^{1}-\mathrm{L}-\mathrm{X}^{2}-\mathrm{D}-$ MeAsp ${ }^{3}-L_{-Z} Z^{4}-A_{d d a}{ }^{5}-D-G l u^{6}-M_{D h a}{ }^{7}$ ), where D-MeAsp is D-erythro- $\beta$-methylaspartic acid, and Mdha is $\mathrm{N}$-methyldehydroalanine. As an example, the sequence of MC-LR has $\mathrm{X}=$ leucine and $\mathrm{Z}=$ arginine [7-9]. There are many sequence variations depending on the identity of the L-amino acid at the $\mathrm{X}^{2}$ and $\mathrm{Z}^{4}$ positions as well as demethylation of D-MeAsp and/or Mdha, and these sequence variations are regarded as MC variants or congeners [10,11]. (2S,3S,8S,9S)-3-Amino-9-methoxy-2,6,8-trimethyl-10phenyldeca-4,6-dienoic acid (Adda) is a common amino acid among the MC variants and is essential for the inhibition of protein phosphatases [12-14]. MCs are taken up by the specific bile acid transport system to hepatocytes $[15,16]$. Binding selectively to protein phosphatase 1 and $2 \mathrm{~A}$ and inhibiting phosphatase activity, as a result, MCs cause severe damage to the liver $[17,18]$. MCs have also been reported to promote the development of liver tumors [17,19]. Moreover, they were reported that MCs have genotoxic potentials [20-22] and affects other organs such as heart, kidney and lung $[21,23,24]$.

MC-LR is one of the first detected microcystins, and many studies on its toxic effects have since been conducted both in vitro [20,25,26] and in vivo [18,27-30]. The World Health Organization (WHO) adopted a provisional guideline value of $1 \mu \mathrm{g} / \mathrm{L}$ for a maximum concentration of MC-LR in drinking water [31]. A couple of reports evaluated the toxicity of each MC variant as a relative value to that of the toxicity of MC-LR [10,32]. Numerous MC variants have been identified from environmental water around the world [33-36]. Therefore it is important to evaluate the toxicity and environmental behavior of MCs and variants in environment water. However, there is not sufficient information of the cytotoxicity in various MC variants, although some studies for cytotoxicities of MC variants were reported [37-39].

In this study, we evaluated the cytotoxicity of $16 \mathrm{MC}$ variants to primary cultured rat hepatocytes. Primary cultured rat hepatocytes were chosen in this study because there were reported that MC-LR induces severe toxicity to the rat liver in vivo [28,29] and causes cytotoxic effects in the hepatocyte [22,40,41]. Moreover, in the present study, we examined the correlation between the cytotoxicity and the amino acid constituents of the $\mathrm{MC}$ variants. 


\section{Results}

We evaluated the cytotoxicities of $16 \mathrm{MC}$ variants. Their structures are shown in Figure 1. Figure 2 shows the dose response curves of primary cultured rat hepatocytes after exposure to five MC-LR variants, namely $\left[\mathrm{Dha}^{7}\right] \mathrm{MC}-\mathrm{LR},\left[\mathrm{D}-\mathrm{Asp}^{3}\right] \mathrm{MC}-\mathrm{LR},\left[\mathrm{D}-\mathrm{Asp}^{3}, \mathrm{Dha}^{7}\right] \mathrm{MC}-\mathrm{LR},\left[\mathrm{D}-\mathrm{Asp}^{3}, E-\mathrm{Dhb}^{7}\right] \mathrm{MC}-\mathrm{LR}$ and $\left[\mathrm{D}-\mathrm{Asp}^{3}, Z-\mathrm{Dhb}^{7}\right] \mathrm{MC}-\mathrm{LR}$. These five MC-LR variants exhibited higher cytotoxic activities than MC-LR. The $\mathrm{IC}_{50}$ values of the MC variants are listed in Table 1 . Based on the $\mathrm{IC}_{50}$ values, the cytotoxic potentials of the MC-LR variants were determined. The cytotoxic potentials of the MC-LR variants are ranked as follows: [D-Asp $\left.{ }^{3}, Z-\mathrm{Dhb}^{7}\right] \mathrm{MC}-\mathrm{LR}>\left[\mathrm{D}-\mathrm{Asp}^{3}, E-\mathrm{Dhb}^{7}\right] \mathrm{MC}-\mathrm{LR}>\left[\mathrm{D}-\mathrm{Asp}^{3}\right.$, $\left.\mathrm{Dha}^{7}\right] \mathrm{MC}-\mathrm{LR}=\left[\mathrm{D}-\mathrm{Asp}^{3}\right] \mathrm{MC}-\mathrm{LR}=\left[\mathrm{Dha}^{7}\right] \mathrm{MC}-\mathrm{LR}>\mathrm{MC}-\mathrm{LR}($ Table 1$)$.

Figure 1. Structures of the $M C$ variants. $M C$ variants are cyclic peptides consisting of seven amino acids. The sequence position numbers of the amino acids number are denoted by a superscript.

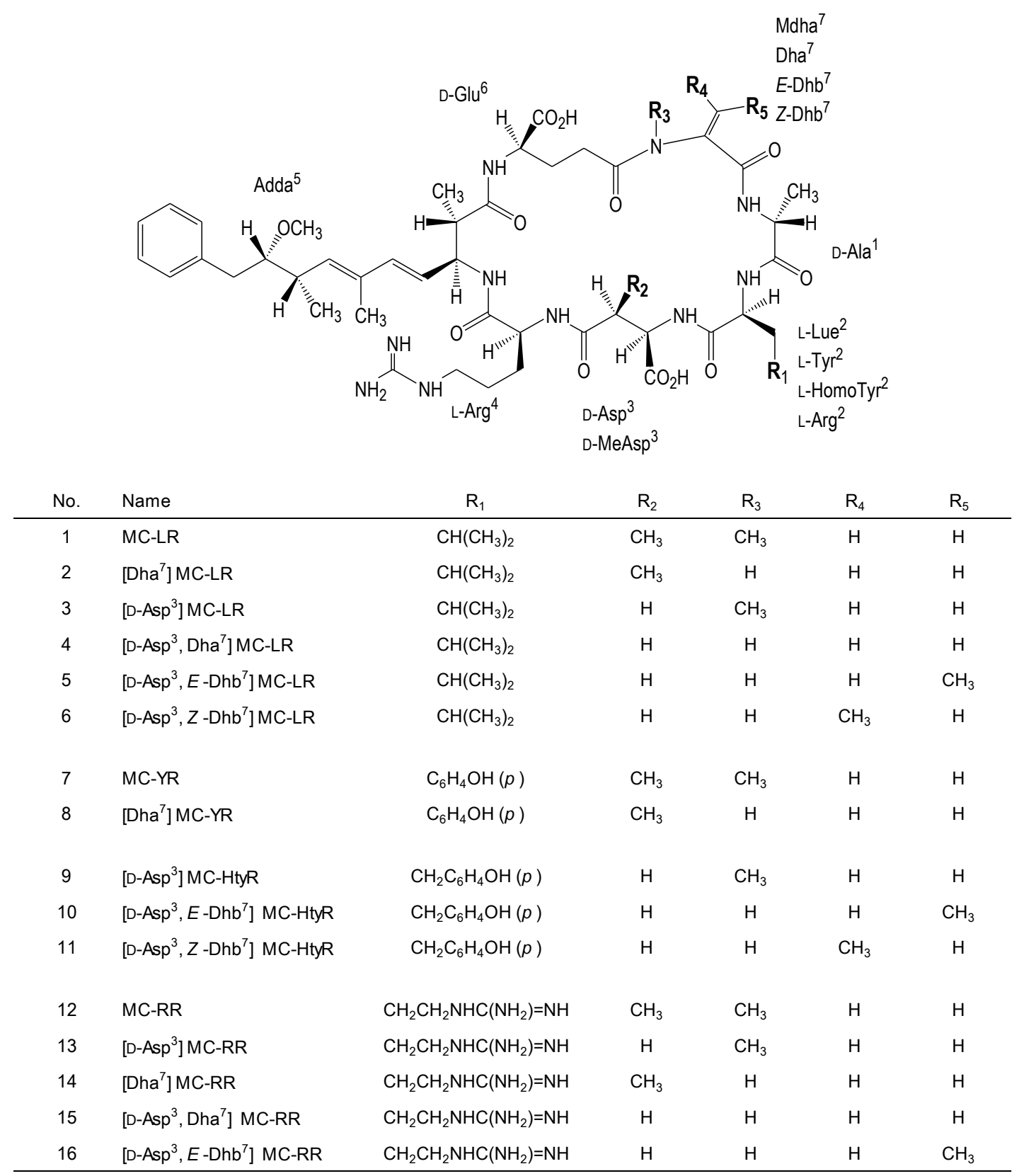


[Dha ${ }^{7}$ ] MC-LR and [D-Asp ${ }^{3}$ ] MC-LR are demethylated at the $\mathrm{R}_{3}$ and $\mathrm{R}_{2}$ positions, respectively, compared to MC-LR, and their cytotoxic activities were found to be higher than that of MC-LR. $\left[\mathrm{D}-\mathrm{Asp}^{3}, Z-\mathrm{Dhb}^{7}\right] \mathrm{MC}-\mathrm{LR}$ and $\left[\mathrm{D}-\mathrm{Asp}^{3}, E-\mathrm{Dhb}^{7}\right] \mathrm{MC}-\mathrm{LR}$, which contain substituted methyl groups at the $\mathrm{R}_{4}$ and $\mathrm{R}_{5}$ positions, respectively, were also highly cytotoxic (Figure 2 ).

Figure 2. Cytotoxicities of the MC-LR variants in primary cultured rat hepatocytes after 72-h exposure, determined by the cell viability assay. Primary cultured rat hepatocytes were exposed to purified MC-LR, [Dha $\left.{ }^{7}\right] \mathrm{MC}-\mathrm{LR},\left[\mathrm{D}-\mathrm{Asp}^{3}\right] \mathrm{MC}-\mathrm{LR},\left[\mathrm{D}-\mathrm{Asp}^{3}, \mathrm{Dha}^{7}\right]$ MC-LR, [D-Asp $\left.{ }^{3}, E-\mathrm{Dhb}^{7}\right]$ MC-LR, [D-Asp $\left.{ }^{3}, Z-\mathrm{Dhb}^{7}\right]$ MC-LR. After $72 \mathrm{~h}$ of exposures, cytotoxicities were determined by the cell viability assay and the values are shown as $\%$ viability. Results are presented as the mean $\pm \mathrm{SD}$ of three independent experiments. * Significantly different from the control: $p<0.05$. (Compounds No.1: MC-LR $(\diamond)$; No.2: [Dha $\left.{ }^{7}\right]$ MC-LR ( $\left.\boldsymbol{\Delta}\right)$; No.3: [D-Asp $\left.{ }^{3}\right]$ MC-LR (o); No.4: [D-Asp ${ }^{3}$, Dha $\left.^{7}\right]$ MC-LR ( $\left.\mathbf{a}\right)$; No.5: $\left[\mathrm{D}-\mathrm{Asp}^{3}, E-\mathrm{Dhb}^{7}\right] \mathrm{MC}-\mathrm{LR}(\Delta)$; No.6: $\left.\left[\mathrm{D}-\mathrm{Asp}^{3}, Z-\mathrm{Dhb}^{7}\right] \mathrm{MC}-\mathrm{LR}(\square)\right)$.

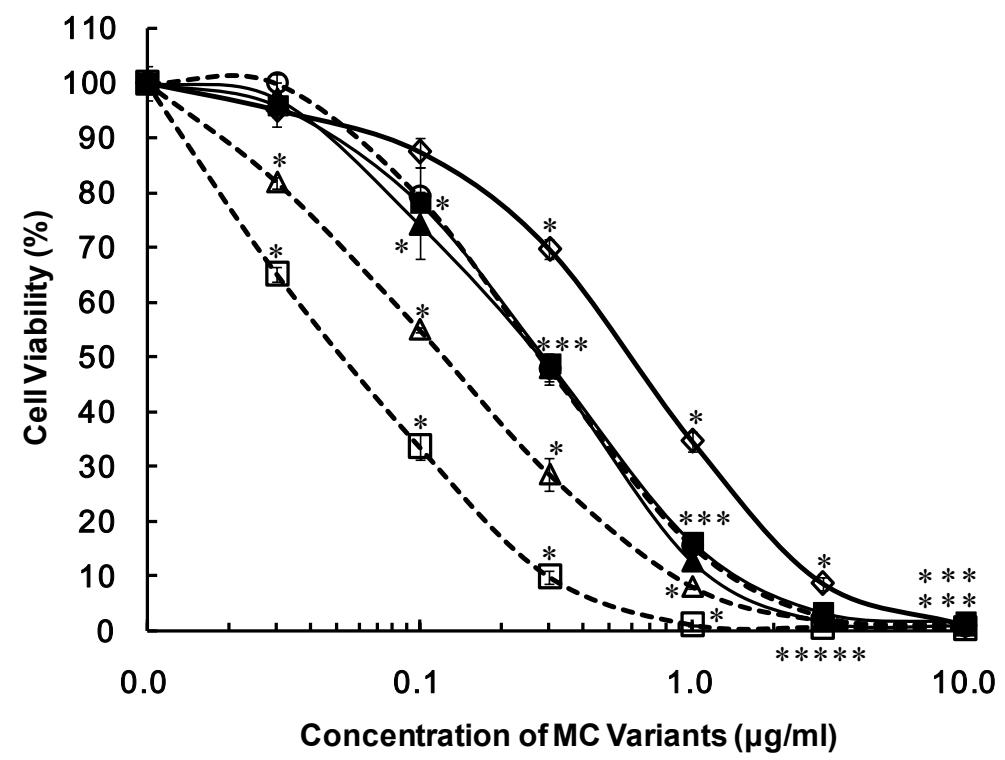

[Dha $\left.{ }^{7}\right] \mathrm{MC}-\mathrm{YR}$ and three MC-HtyR variants showed higher cytotoxic activities than those of MC-YR and -LR (Figure 3). The $\mathrm{IC}_{50}$ values are ranked as follows: $\mathrm{MC}-\mathrm{YR}>$ [Dha ${ }^{7} \mathrm{MC}-\mathrm{YR}>$ [D-Asp $\left.{ }^{3}\right]$ MC-HtyR $>\left[\right.$ D-Asp ${ }^{3}, E-$ Dhb $\left.^{7}\right]$ MC-HtyR $>\left[\right.$ D-Asp $\left.{ }^{3}, Z-\mathrm{Dhb}^{7}\right]$ MC-HtyR (Table 1). [Dha $\left.{ }^{7}\right]$ MC-YR, which is a demethylated variant (at the $\mathrm{R}_{3}$ position) of MC-YR, caused an increase in cytotoxic activity relative to MC-YR (Figures 1 and 3).

[D-Asp ${ }^{3}, Z-\mathrm{Dhb}^{7}$ ] MC-HtyR, which has a methyl group at the $\mathrm{R}_{4}$ position, exhibited significantly high cytotoxic activity, compared to $\left[\mathrm{D}-\mathrm{Asp}^{3}, E-\mathrm{Dhb}^{7}\right] \mathrm{MC}-\mathrm{HtyR}$, which has a methyl group at the $\mathrm{R}_{5}$ position (Figures 1 and 3).

MC-RR was less cytotoxic than both MC-LR and -YR (Table 1). Four MC-RR variants exhibited higher cytotoxic activities than MC-RR (Figure 4). [Dha $\left.{ }^{7}\right] \mathrm{MC}-\mathrm{RR}$, which lacks a methyl group at the $\mathrm{R}_{3}$ position of MC-RR, induced a slightly high cytotoxic activity relative to [D-Asp ${ }^{3}$ ] MC-RR, which lacks a methyl group at the $\mathrm{R}_{2}$ position of MC-RR (Figure 4). 
Figure 3. Cytotoxicities of the MC-YR variants in primary cultured rat hepatocytes after 72-h exposure, determined by the cell viability assay. Primary cultured rat hepatocytes were exposed to MC-LR, MC-YR, [Dha $\left.{ }^{7}\right] \mathrm{MC}-\mathrm{YR},\left[\mathrm{D}-\mathrm{Asp}^{3}\right] \mathrm{MC}-\mathrm{HtyR},\left[\mathrm{D}-\mathrm{Asp}^{3}, E-\mathrm{Dhb}^{7}\right]$ MC-HtyR, [D-Asp ${ }^{3}, Z-\mathrm{Dhb}^{7}$ ] MC-YR. After $72 \mathrm{~h}$ of exposures, cytotoxicities were determined by the cell viability assay and the values were shown as $\%$ viability. Results are presented as the mean $\pm \mathrm{SD}$ of three independent experiments. * Significantly different from the control: $p<0.05$. (Compounds No.1: MC-LR $(\diamond)$; No.7: MC-YR $(\diamond)$; No.8: $\left[\mathrm{Dha}^{7}\right]$ MC-YR ( $\left.\boldsymbol{\Delta}\right)$; No.9: [D-Asp ${ }^{3}$ ] MC-HtyR (o); No.10: [D-Asp ${ }^{3}, E-$ Dhb $^{7}$ ] MC-HtyR ( $\left.\Delta\right)$; No.11: [D-Asp $\left.{ }^{3}, Z-\mathrm{Dhb}^{7}\right]$ MC-HtyR (口)).

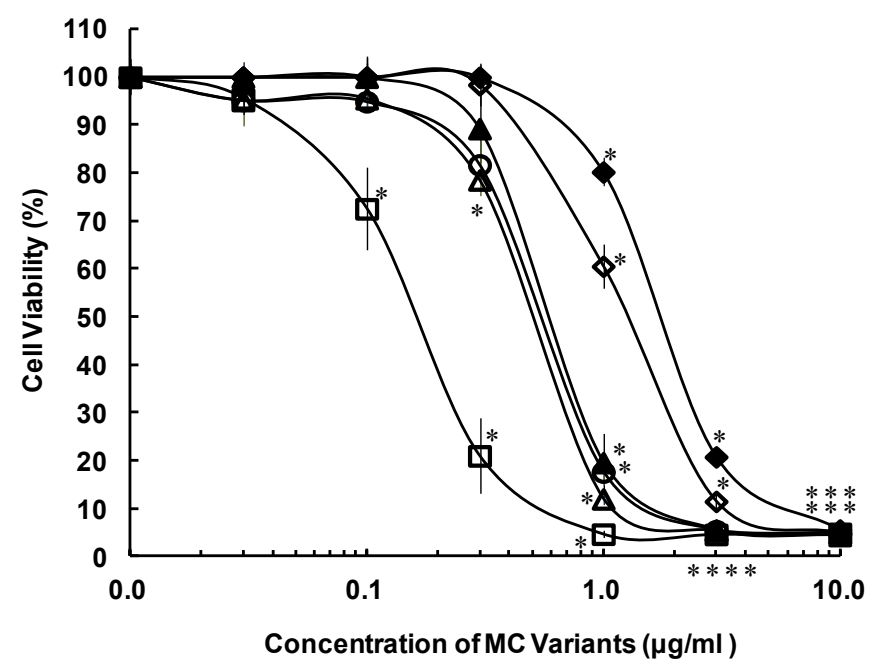

Figure 4. Cytotoxicities of the MC-RR variants in primary cultured rat hepatocytes after 72-h exposure, determined by the cell viability assay. Primary cultured rat hepatocytes were exposed to MC-LR, MC-RR, [D-Asp ${ }^{3}$ ] MC-RR, [Dha ${ }^{7}$ MC-RR, [D-Asp ${ }^{3}$, Dha ${ }^{7}$ MC-RR, $\left[\mathrm{D}-\mathrm{Asp}^{3}, E-\mathrm{Dhb}^{7}\right] \mathrm{MC}-\mathrm{RR}$. After $72 \mathrm{~h}$ of exposures, cytotoxicities were determined by the cell viability assay and the values were shown as \% viability. Results are presented as the mean \pm SD of three independent experiments. * Significantly different from the control: $p<0.05$. (Compounds No.1: MC-LR $(\diamond)$; No.12: MC-RR $(\bullet)$; No.13: [D-Asp ${ }^{3}$ ] MC-RR

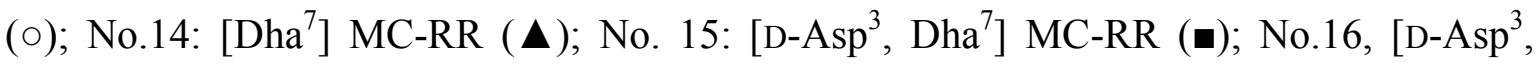
$\left.\left.E-\mathrm{Dhb}^{7}\right] \mathrm{MC}-\mathrm{RR}(\Delta)\right)$.

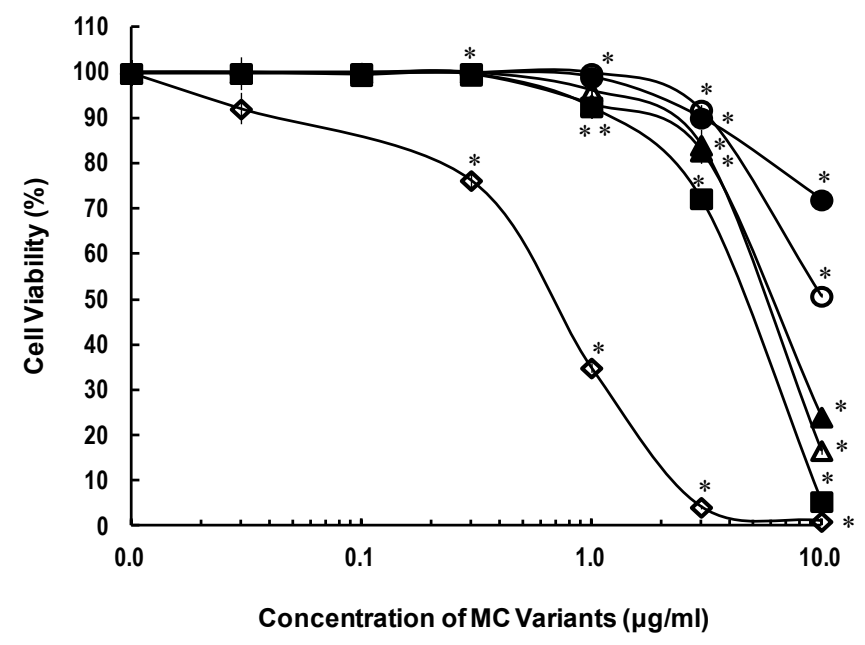


Table 1. Comparison of the $\mathrm{IC}_{50}$ of $\mathrm{MC}$ variants. Each $\mathrm{IC}_{50}$ value was estimated from the $50 \%$ viability concentration shown in Figures $2-4$. Data are arranged in the order of increasing cytotoxic activity.

\begin{tabular}{|c|c|c|}
\hline No. & MC variants name & $\mathrm{IC}_{50}(\mu \mathrm{g} / \mathrm{mL})$ \\
\hline 6 & {$\left[\mathrm{D}-\mathrm{Asp}^{3}, Z-\mathrm{Dhb}^{7}\right] \mathrm{MC}-\mathrm{LR}$} & 0.053 \\
\hline 11 & {$\left[\mathrm{D}-\mathrm{Asp}^{3}, Z-\mathrm{Dhb}^{7}\right] \mathrm{MC}-\mathrm{HtyR}$} & 0.120 \\
\hline 5 & {$\left[\mathrm{D}-\mathrm{Asp}^{3}, E-\mathrm{Dhb}^{7}\right] \mathrm{MC}-\mathrm{LR}$} & 0.133 \\
\hline 4 & {$\left[\mathrm{D}-\mathrm{Asp}^{3}, \mathrm{Dha}^{7}\right] \mathrm{MC}-\mathrm{LR}$} & 0.217 \\
\hline 3 & {$\left[\mathrm{D}-\mathrm{Asp}^{3}\right] \mathrm{MC}-\mathrm{LR}$} & 0.217 \\
\hline 2 & {$\left[\mathrm{Dha}^{7}\right] \mathrm{MC}-\mathrm{LR}$} & 0.217 \\
\hline 10 & {$\left[\mathrm{D}-\mathrm{Asp}^{3}, E-\mathrm{Dhb}^{7}\right] \mathrm{MC}-\mathrm{HtyR}$} & 0.327 \\
\hline 9 & {$\left[\mathrm{D}-\mathrm{Asp}^{3}\right] \mathrm{MC}-\mathrm{HtyR}$} & 0.347 \\
\hline 8 & {$\left[\mathrm{Dha}^{7}\right] \mathrm{MC}-\mathrm{YR}$} & 0.418 \\
\hline 1 & MC-LR & 0.800 \\
\hline 7 & MC-YR & 1.48 \\
\hline 15 & {$\left[\mathrm{D}-\mathrm{Asp}^{3}, \mathrm{Dha}^{7}\right] \mathrm{MC}-\mathrm{RR}$} & 4.11 \\
\hline 16 & {$\left[\mathrm{D}-\mathrm{Asp}^{3}, E-\mathrm{Dhb}^{7}\right] \mathrm{MC}-\mathrm{RR}$} & 4.95 \\
\hline 14 & {$\left[\mathrm{Dha}^{7}\right] \mathrm{MC}-\mathrm{RR}$} & 5.33 \\
\hline 13 & [D-Asp $\left.{ }^{3}\right] \mathrm{MC}-\mathrm{RR}$ & $>10$ \\
\hline 12 & MC-RR & $>10$ \\
\hline
\end{tabular}

\section{Discussion}

We evaluated the cytotoxicities of $\mathrm{MC}$ variants isolated from some cyanobacteria to primary cultured rat hepatocytes. Accumulation of toxicity information for $\mathrm{MC}$ variants is absolutely essential to conduct the risk assessment or management of them. Therefore, toxic properties of $16 \mathrm{MV}$ variants indicated in this study would be helpful basic information for the risk assessment or management of many $\mathrm{MC}$ variants in environmental water.

In this study, $\mathrm{IC}_{50}$ of MC-LR to primary rat hepatocytes was $0.8 \mu \mathrm{g} / \mathrm{mL}$, however earlier study was reported that $\mathrm{IC}_{50}$ of MC-LR to the same cells was $48 \mathrm{ng} / \mathrm{mL}$ [42]. The MTT assay used in the earlier study and the assay which measure the cellular ATP contents (ATP assay) show occasional different $\mathrm{IC}_{50}$ with certain differences of cell lines, exposure chemicals, number of cells etc. [43,44]. Therefore, the difference of $\mathrm{IC}_{50}$ might be attributed to these assay methods to evaluate the cell viability. Moreover, in this study, we used the freeze-thawed cells and seeded 2.5-fold of cell number compared to the cell number in the earlier study. These differences might have caused the reduction of the cytotoxicity. We think that it is important to evaluate the result taking the difference of the experimental methods into consideration in the risk assessment or management.

Lack of a methyl group at either the $\mathrm{R}_{3}$ or $\mathrm{R}_{2}$ position of $\mathrm{Dha}^{7}$ or $\mathrm{D}-\mathrm{Asp}^{3}$, resulted in enhanced cytotoxic activities of MC-LR, -YR, and -RR. In particular, for MC-RR, the lack of a methyl group at the $\mathrm{R}_{3}$ position might be responsible for the slight enhancement of cytotoxic activity, compared to demethylation at the $\mathrm{R}_{2}$ position (Figure 4 ).

It has been reported that $\left[\mathrm{Asp}^{3}, \mathrm{Dhb}^{7}\right] \mathrm{MC}-\mathrm{RR}$ exhibits higher cytotoxicity than MC-RR $[45,46]$. In this study, D-Asp ${ }^{3}$ and $E-\mathrm{Dhb}^{7}$ or $\mathrm{D}-\mathrm{Asp}^{3}$ and $Z-\mathrm{Dhb}^{7}$ on MC-LR and -HtyR also induced higher cytotoxic activities than $\mathrm{D}-\mathrm{Asp}^{3}$ or $\mathrm{Dha}^{7}$ on MC-LR and -HtyR. These results suggest that substitution 
of the methyl group at the $\mathrm{R}_{4}$ or $\mathrm{R}_{5}$ positions is associated with cytotoxic potential, rather than the lack of a methyl group at the $\mathrm{R}_{3}$ or $\mathrm{R}_{2}$ positions. In fact, [D-Asp ${ }^{3}, Z-\mathrm{Dhb}^{7}$ ] MC-LR exhibited the strongest cytotoxic activity among the 16 variants, and [D-Asp $\left.{ }^{3}, Z-\mathrm{Dhb}^{7}\right] \mathrm{MC}-\mathrm{HtyR}$ also exhibited high cytotoxicity. A comparison of the $\mathrm{IC}_{50}$ values among [D-Asp $\left.{ }^{3}, Z-\mathrm{Dhb}^{7}\right]$ and $\left[\mathrm{D}-\mathrm{Asp}^{3}, E-\mathrm{Dhb}^{7}\right.$ ] on MC-LR and -HtyR suggests that the presence of a methyl group at the $\mathrm{R}_{4}$ position caused stronger effects on cytotoxic activity than the presence of a methyl group at the $\mathrm{R}_{5}$ position (Table 1). Although the D-Asp ${ }^{3}$ residue may be essential for the enhancement of cytotoxicity, the $\mathrm{R}_{4}$ methyl group of the $Z$-Dhb ${ }^{7}$ residue may also play a key role in the cytotoxic activities of MCs such as the Adda moiety.

Distinct properties of MC variants in terms of uptake, cytotoxicity, protein phosphatase 1 and 2A inhibition, were reported in other organisms cells, brain and neuron cells of mice or Caco-2 cells from human $[37-39,47]$. It is thought that MC variants with the same hydrophobic properties show the same permeabilities to the cell membrane. Vesterkvist et al. suggested that the hydrophobic MC has pronounced cytotoxic potentials in Caco-2 cells [38]. Since [D-Asp ${ }^{3}, Z-$ Dhb $^{7}$ ]-MC-LR and -HtyR are geometric isomers of $\left[\mathrm{D}-\mathrm{Asp}^{3}, E-\mathrm{Dhb}^{7}\right]-\mathrm{MC}-\mathrm{LR}$ and -HtyR, respectively, they have same hydrophobic property. However, the $Z$ geometric isomers had more potent cytotoxic activities than the $E$ geometric isomers in primary cultured rat hepatocytes in our study. Therefore, at $\mathrm{R}_{4}$ and $\mathrm{R}_{5}$ position of 7 th amino acid (Mdha, Dha or Dhb), the conformational property would be an important factor for cytotoxicity to rat hepatocytes. Differences in the response of the proteins on cell surface or inside the cell, which are caused by differences of the conformational property, might determine the toxic potentials. While the protein phosphatase inhibition activities of MCs were reported in various studies, it was reported that the activity with $\mathrm{MC}$ variants did not correlate with their toxic potential $[38,46]$. There is little information of cellular uptake of MC variants in each organ. More information on membrane permeability, cellular uptake in various organs or species, interaction with target proteins etc. is needed to fully understand different toxic potentials of MC variants.

\section{Experimental Section}

\subsection{Variants}

The $16 \mathrm{MC}$ variants were separated and purified by high performance liquid chromatography. The details of the separation procedure have been described in a previous report [48]. MC-LR, [D-Asp ${ }^{3}$, $\left.\mathrm{Dha}^{7}\right] \mathrm{MC}-\mathrm{LR},\left[\mathrm{Dha}^{7}\right] \mathrm{MC}-\mathrm{LR}, \mathrm{MC}-\mathrm{YR},\left[\mathrm{Dha}^{7}\right] \mathrm{MC}-\mathrm{YR}, \mathrm{MC}-\mathrm{RR},\left[\mathrm{Dha}^{7}\right] \mathrm{MC}-\mathrm{RR}$ and [D-Asp $\left.{ }^{3}, \mathrm{Dha}^{7}\right]$ MC-RR were obtained from cultured Microcystis aeruginosa (NIES-90). [D-Asp ${ }^{3}$ ] MC-LR, [D-Asp ${ }^{3}$ ] MC-HtyR and [D-Asp ${ }^{3}$ ] MC-RR were obtained from Planktothrix agardhii (NIES-595 and NIES-1263). $\left[\mathrm{D}-\mathrm{Asp}^{3}, \quad Z-\mathrm{Dhb}^{7}\right] \mathrm{MC}-\mathrm{LR}$ and $\left[\mathrm{D}-\mathrm{Asp}^{3}, Z-\mathrm{Dhb}^{7}\right]$ MC-HtyR were isolated from bloom of Planktothrix agardhii [49]. [D-Asp ${ }^{3}, E-\mathrm{Dhb}^{7}$ ] MC-LR, [D-Asp ${ }^{3}, E-\mathrm{Dhb}^{7}$ ] MC-HtyR and [D-Asp ${ }^{3}$, $E$-Dhb $\left.{ }^{7}\right]$ MC-RR were obtained from cultured Planktothrix rubescens (NIES-610 and NIES-928). The accurate concentrations of isolated MC variant solutions were determined based on the absorbance at $238 \mathrm{~nm}$ using the molar extinction coefficient (42000). The structures of these MC variants are shown in Figure 1. 


\subsection{Cells}

Primary cultured rat hepatocytes, which maintain both phase I and II metabolic activity as well as uptake transporter activity, were isolated from Sprague Dawley. The cells were purchased from Biopredic International (Rennes, France) and were stored at $-135{ }^{\circ} \mathrm{C}$ until further use. Thawing medium, seeding medium, and long-term culture medium were purchased from Biopredic International (Rennes, France). The primary cultured rat hepatocytes were thawed in a water bath at $37{ }^{\circ} \mathrm{C}$. The cells were poured into $30 \mathrm{~mL}$ of pre-warmed thawing medium. The cell suspension was centrifuged at $900 \mathrm{rpm}(160 \times \mathrm{g})$ for $1 \mathrm{~min}$. The supernatant was removed and the cell pellets were re-suspended in $2 \mathrm{~mL}$ of the seeding medium. The cells were seeded in 96 -well white plates at $0.3 \times 10^{6}$ cells $/ \mathrm{mL}$ in $0.1 \mathrm{~mL} /$ well of the seeding medium and incubated at $37^{\circ} \mathrm{C}$ in $5 \% \mathrm{CO}_{2}$. The following day, the cells were exposed to sixteen $\mathrm{MC}$ variants with the long-term culture medium.

\subsection{Cytotoxicity Assay}

MC variants were dissolved in a mixture of DMSO:water $=9: 1(v / v)$ to make $1.0 \mathrm{mg} / \mathrm{mL}$ stock solutions taking the solubility of MC variants to DMSO into consideration. Stock solutions were diluted to $3-1000 \mu \mathrm{g} / \mathrm{mL}$ with DMSO, and subsequently diluted to final concentrations of $0.03-10 \mu \mathrm{g} / \mathrm{mL}$ in the medium. 1\% DMSO solution was diluted 100-fold with the medium, and the resulting solution was used as a negative control. Cells were seeded in 96-well white plates and pre-cultured at $37{ }^{\circ} \mathrm{C}$ in $5 \% \mathrm{CO}_{2}$ overnight. Cells were then exposed to various concentrations of $\mathrm{MC}$ variants in the long-term culture medium for $72 \mathrm{~h}$. Cytotoxicity was evaluated using the Cell Titer-Glo Luminescent Cell Viability Assay Kit (Promega Corporation, Madison, WI, USA), based on cellular ATP content. After $10 \mathrm{~min}$ of incubation with an equal volume of the Cell Titer-Glo reagent at room temperature, luminescence was measured for $1 \mathrm{~s} /$ well. The luminescence intensity of each well treated with an MC variant was determined, relative to the control, and those concentrations of the $\mathrm{MC}$ variants that showed $50 \%$ cell viability $\left(\mathrm{IC}_{50}\right)$ were calculated. $\mathrm{MC}$-LR was used as a positive reference substance for every assay.

\subsection{Statistical Analysis}

All experiments values were expressed as the mean \pm standard deviations (SD) of three independent experiments. The results were analyzed statistically with the Student's $t$-test. The test was conducted to verify the difference between each group exposed to MC variants and the control. Differences with $p<0.05$ were considered statistical significant.

\section{Conclusions}

We have determined the cytotoxic potentials of 16 types of $\mathrm{MC}$ variants primary culture rat hepatocytes. $\mathrm{MC}$ variants containing $\mathrm{D}-\mathrm{Asp}^{3}$ and $\mathrm{Dha}^{7}$ and/or $\mathrm{Dhb}^{7}$ residues were found to exhibit stronger cytotoxic activities than their corresponding normal MC variants. The $Z-\mathrm{Dhb}^{7}$ residue of the $\mathrm{MC}$ variants is important for their cytotoxic potential. Toxic properties of $16 \mathrm{MC}$ variants indicated in this study would help accumulation of toxicity basic information on various MCs, and eventually contribute to the risk assessment and/or management of environmental water. 


\section{Acknowledgments}

This work was supported by a research grant from the Ministry of the Environment of Japan and the Ministry of Health, Labour and Welfare in Japan.

\section{Conflicts of Interest}

The authors declare that there are no conflict of interest.

\section{References}

1. Jochimsen, E.M.; Carmichael, W.W.; An, J.; Cardo, D.M.; Cookson, S.T.; Holmes, C.E.; Antunes, M.B.C.; de Melo Filho, D.A.; Lyra, T.M.; Barreto, V.S.T.; et al. Liver failure and death after exposure to microcystins at a hemodialysis center in Brazil. N. Engl. J. Med. 1998, 338, 873-878.

2. Codd, G.A.; Bell, S.G.; Kaya, K.; Ward, C.J.; Beattle, K.A.; Metcalf, J.S. Cyanobacterial toxins, exposure routes and human health. Eur. J. Physiol. 1999, 34, 405-415.

3. Krishnamurthy, T.; Carmichael, W.W.; Sarver, E.W. Toxic peptides from freshwater cyanobacteria (blue-green algae). I. Isolation, purification and characterization of peptides from Microcysis aeruginosa and Anabaena flos-aquae. Toxicon 1986, 24, 865-873.

4. Watanabe, M.F.; Oishi, S.; Harada, K.; Matsuura, K.; Kawai, H.; Suzuki, M. Toxins contained in Microcystis species of cyanobacteria (blue-green algae). Toxicon 1988, 26, 1017-1025.

5. Paerl, H.W.; Otten, T.G. Harmful cyanobacterial blooms: Causes, consequences, and controls. Microb. Ecol. 2013, 65, 995-1010.

6. Sukenik, A.; Hadas, O.; Kaplan, A.; Quesada, A. Invasion of nostocales (cyanobacteria) to subtropical and temperate freshwater lakes-Physiological, regional, and global driving forces. Front. Microbiol. 2012, 3, doi:10.3389/fmicb.2012.00086.

7. Botes, D.P.; Tuinman, A.A.; Wessels, P.L.; Viljoen, C.C.; Kruger, H.; Williams, D.H.; Santikarn, S.; Smith, R.J.; Hammond, S. The structure of cyanoginosin-LA, a cyclic heptapeptide toxin from the cyanobacterium Microcysis aeruginosa. J. Chem. Soc. Perkin Trans. 1984, 1, 2311-2318.

8. Krishnamurthy, T.; Szafraniec, L.; Hunt, D.F.; Shabanowitz, J.; Yates, J.R., III; Hauer, C.R.; Carmichael, W.W.; Skulberg, O.; Codd, G.A.; Missler, S. Structural characterization of toxic cyclic peptides from blue-green algae by tandem mass spectrometry. Proc. Natl. Acad. Sci. USA 1989, 86, 770-774.

9. Rudolph-Böhner, S.; Mierke, D.F.; Moroder, L. Molecular structure of the cyanobacterial tumor-promoting microcystins. FEBS Lett. 1994, 349, 319-323.

10. Van Apeldoorn, M.E.; van Egmond, H.P.; Speijers, G.J.A.; Bakker, G.J.I. Toxins of cyanobacteria. Mol. Nutr. Food Res. 2007, 51, 7-60.

11. Welker, M.; Brunke, M.; Preussel, K.; Lippert, I.; van Döhren, H. Diversity and distribution of Mycrocystis (Cyanobacteria) oligopeptide chemotypes from natural communities studied by single-colony mass spectrometry. Microbiology 2004, 150, 1785-1796. 
12. Harada, K.; Matsuura, K.; Suzuki, M.; Watanabe, M.F.; Oishi, S.; Dahlem, A.M.; Beasley, V.R.; Carmicheal, W.W. Isolation and characterization of the minor components associated with microcystins LR and RR in the cyanobacterium (blue-green algae). Toxicon 1990, 28, 55-64.

13. Harada, K.; Ogawa, K.; Matsuura, K.; Murata, H.; Suzuki, M.; Watanabe, M.F.; Itezono, Y.; Nakayama, N. Structural determination of geometrical isomers of microcystins LR and RR from cyanobacteria by two-dimensional NMR spectroscopic techniques. Chem. Res. Toxicol. 1990, 3, 473-481.

14. An, J.; Carmichael, W.W. Use of a colorimetric protein phosphatase inhibition assay and enzyme linked immunosorbent assay for the study of microcystins and nodularins. Toxicon 1994, 32, 1495-1507.

15. Eriksson, J.E.; Grönberg, L.; Nygård, S.; Slotte, J.P.; Meriluoto, J.A.O. Hepatocellular uptake of ${ }^{3} \mathrm{H}$-dihydromicrocystin-LR, a cyclic peptide toxin. Biochim. Biophys. Acta 1990, 1025, 60-66.

16. Fischer, W.J.; Altheimer, S.; Cattori, J.; Meier, P.J.; Dietrich, D.R.; Hagenbuch, B. Organic anion transporting polypeptides expressed in liver and brain mediate uptake of microcystin. Toxicol. Appl. Pharmacol. 2005, 203, 257-263.

17. Runnegar, M.T.; Kong, S.; Berndt, N. Protein phosphatase inhibition and in vivo hepatotoxicity of microcystins. Am. J. Physiol. 1993, 265, G224-G230.

18. Yoshida, T.; Makita, Y.; Nagata, S.; Tsutsumi, T.; Yoshida, F.; Sekijima, M.; Tamura, S.; Ueno, Y. Acute oral toxicity of microcystin-LR, a cyanobacterial hepatotoxin, in mice. Nat. Toxins 1997, 5, 91-95.

19. MacKintosh, C.; Beattie, K.A.; Klumpp, S.; Choen, P.; Codd, G.A. Cyanobacterial microcystin-LR is a potent and specific inhibitor of protein phosphatases 1 and $2 \mathrm{~A}$ from both mammals and higher plants. FEBS Lett. 1990, 264, 187-192.

20. Žegura, B.; Gajski, G.; Štraser, A.; Garaj-Vrhovac, V.; Filipič, M. Microcystin-LR induced DNA damage in human peripheral blood lymphocytes. Mutat. Res. 2011, 726, 116-122.

21. Soares, R.M.; Cagido, V.R.; Ferraro, R.B.; Meyer-Fernandes, J.R.; Rocco, P.R.; Zin, W.A.; Azevedo, S.M. Effects of microcystin-LR on mouse lungs. Toxicon 2007, 50, 330-338.

22. Bouaïcha, N.; Maatouk, I.; Plessis, M.J.; Périn, F. Genotoxic potential of microcystin-LR and in vitro in primary cultured rat hepatocytes and in vivo in rat liver. Environ. Toxicol. 2005, 20, 341-347.

23. Šuput, D.; Zorc-Pleskovič, R.; Petrovič, D.; Milutinovič, A. Cardiotoxic injury caused by chronic administration of microcystin-YR. Folia Biol. 2010, 56, 14-18.

24. Nobre, A.C.; Jorge, M.C.; Menezes, D.B.; Fonteles, M.C.; Monteiro, H.S. Effects of microcystin-LR in isolated perfused rat kidney. Braz. J. Med. Biol. Res. 1999, 32, 985-988.

25. Dias, E.; Andrade, M.; Alverca, E.; Pereria, P.; Batoréu, M.C.; Jordan, P.; Silva, M.J. Comparative study of the cytotoxic effect of microcystin-LR and purified extracts from Microcystis aeruginosa on a kidney cell line. Toxicon 2009, 53, 487-495.

26. Li, T.; Ying, L.; Wang, H.; Li, N.; Fu, W.; Guo, Z.; Xu, L. Microcystin-LR induces ceramide to regulate PP2A and destabilize cytoskeleton in HEK293 cells. Toxicol. Sci. 2012, 128, 147-157.

27. Gaudin, J.; Le Hegarat, L.; Nesslany, F.; Marzin, D.; Fessard, V. In vivo genotoxic potential of microcystin-LR: A cyanobacterial toxin, in investigated both by the unscheduled DNA synthesis (UDS) and the comet assays after intravenous administration. Environ. Toxicol. 2008, 24, 200-209. 
28. Hooser, S.B.; Beasley, V.R.; Lovell, R.A.; Carmichael, W.W.; Haschek, W.M. Toxicity of microcystin LR, a cyclic heptapeptide hepatotoxin from Microcystis aeruginosa, to rats and mice. Vet. Pathol. 1989, 26, 246-252.

29. Hooser, S.B. Fulminant hepatocyte apoptosis in vivo following microcystin-LR administration to rats. Toxicol. Pathol. 2000, 28, 726-733.

30. Chen, L.; Zhang, X.; Zhou, W.; Qiao, Q.; Liang, H.; Li, G.; Wang, J.; Cai, F. The Interactive effects of cytoskeleton disruption and mitochondria dysfunction lead to reproductive toxicity induced by microcystin-LR. PLoS One 2013, 8, e53949.

31. WHO. Guidelines for Drinking-Water Quality, Volume 2, Health Criteria and Other Supporting Information, Addendum, WHO/EOS/98.1; World Health Organization: Geneva, Switzerland, 1998.

32. Nicholson, B.C.; Burch, M.D. Evaluation of Analytical Methods for Detection and Quantification of Cyanotoxins in Relation to Australian Drinking Water Guidelines; The National Health and Medical Research Council of Australia; The Water Services Association of Australia; The Cooperative Research Centre for Water Quality and Treatment: Canberra, Australia, 2001.

33. Namikoshi, M.; Sivonen, K.; Evans, W.R.; Caemichael, W.W.; Rouhiainen, L.; Luukkainen, R.; Rinehart, K.L. Structures of three new homotyrosine-containing microcystins and a new homophenylalanine variant from Anabaena sp. strain 66. Chem. Res. Toxicol. 1992, 5, 661-666.

34. Sivonen, K.; Namikoshi, M.; Evans, W.R.; Färdig, M.; Carmichael, W.W.; Rinehart, K.L. Three new microcystins, cyclic heptapeptides hepatotoxins, from Nostoc sp. strain 152. Chem. Res. Toxicol. 1992, 5, 464-469.

35. Sano, T.; Takagi, H.; Kaya K. A Dhb-microcystin from the filamentous cyanobacterium Planktothrix rubescens. Phytochemistry 2004, 65, 2159-2162.

36. Wood, S.A.; Mountfort, D.; Selwood, A.I.; Holland, P.T.; Puddick, J.; Cary, S.C. Widespread distribution and identification of eight novel microcystins in Antarctic cyanobacterial mats. Appl. Environ. Microbiol. 2008, 74, 7243-7251.

37. Feurstein, D.; Stemmer, K.; Kleinteich, J.; Speicher, T.; Dietrich, D.R. Microcystin congener- and concentration-dependent induction of murine neuron apoptosis and neurite degeneration. Toxicol. Sci. 2011, 124, 424-431.

38. Vesterkvist, P.S.; Misiorek, J.O.; Spoof, L.E.; Toivola, D.M.; Meriluoto, J.A. Comparative cellular toxicity of hydrophilic and hydrophobic microcystins on Caco-2 cells. Toxins 2012, 4, 1008-1023.

39. Huguet, A.; Henri, J.; Petitpas, M.; Hogeveen, K.; Fessard, V. Comparative cytotoxicity, oxidative stress, and cytokine secretion induced by two cyanotoxin variants, microcystin LR and RR, in human intestinal Caco-2 cells. J. Biochem. Mol. Toxicol. 2013, 27, 253-258.

40. Maatouk, I.; Bouaïcha, N.; Plessis, M.J.; Périn, F. Detection by ${ }^{32} \mathrm{P}$-postlabelling of 8-oxo-7,8dihydro-2'-deoxyguanosine in DNA as biomarker of microcystin-LR and nodularin-induced DNA damage in vitro in primary cultured rat hepatocytes and in vivo in rat liver. Mutat. Res. 2004, 564, 9-20.

41. Espiña, B.; Louzao, M.C.; Cagide, E.; Alfonso, A.; Vieytes, M.R.; Yasumoto, T.; Botana, L.M. The methyl ester of okadaic acid is more potent than okadaic acid in disrupting the actin cytoskeleton and metabolism of primary cultured hepatocytes. Br. J. Pharmacol. 2010, 159, 337-344. 
42. Bouaïcha, N.; Maatouk, I. Microcystin-LR and nodularin induce intracellular glutathione alteration, reactive oxygen species production and lipid peroxidation in primary cultured rat hepatocytes. Toxicol. Lett. 2004, 148, 53-63.

43. Ulukaya, E.; Ozdikicioglu, F.; Yilmaztepe, O.; Demirci, M. The MTT assay yields a relatively lower result of growth inhibition than the ATP assay depending on the chemotherapeutic drugs tested. Toxicol. In Vitro 2008, 22, 232-239.

44. Mueller, H.; Kassack, M.U.; Wiese, M. Comparison of the usefulness of the MTT, ATT, and Calcein assay to predict the potency of cytotoxic agents in various human cancer cell lines. $J$. Biomol. Screen. 2004, 9, 506-515.

45. Blom, J.F.; Robinson, J.A.; Jüttner, F. High grazer toxicity of [D-Asp $\left.{ }^{3},(E)-\mathrm{Dhb}^{7}\right]$ microcystin-RR of Planktothrix rubescens as compared to different microcystins. Toxicon 2001, 39, 1923-1932.

46. Blom, J.F.; Jüttner, F. High crustacean toxicity of microcystin congeners does not correlate with high protein phosphatase inhibitory activity. Toxicon 2005, 46, 465-470.

47. Feurstein, D; Holst, K.; Fischer, A.; Dietrich, D.R. Oatp-associated uptake and toxicity of microcystins in primary murine whole brain cells. Toxicol. Appl. Pharmacol. 2009, 234, 247-255.

48. Sano, T.; Takagi, H.; Nishikawa, M.; Kaya, K. NIES certified reference material for microcystins, hepatotoxic cyclic peptide toxins from cyanobacterial blooms in eutrophic water bodies. Anal. Bioanal. Chem. 2008, 391, 2005-2010.

49. Sano, T.; Beattie, K.A.; Codd, G.A.; Kaya, K. Two (Z)-dehydrobutyrine-containing microcystins from a hepatotoxic bloom of Oscillatoria agardhii from Soulseat Loch, Scotland. J. Nat. Prod. 1998, 61, 851-853.

(C) 2013 by the authors; licensee MDPI, Basel, Switzerland. This article is an open access article distributed under the terms and conditions of the Creative Commons Attribution license (http://creativecommons.org/licenses/by/3.0/). 